\title{
Effects of Cutting Conditions and Cold Air on Cutting Temperature in Intermittent Cutting
}

\author{
正 柴坂敏郎（神戸大院） ○学 田辺剛（神戸大院） \\ 林 央（神戸大）＼cjkstart正 森脇俊道（神戸大）
}

Toshiroh SHIBASAKA, Tsuyoshi TANABE, Hisashi HAYASHI and Toshimichi MORIWAKI, Kobe University, 1-1, Rokkodaicho, Nada, Kobe, Hyogo, Japan

Cutting fluids used in metal cutting are sources of pollution and health hazards. Therefore, eco-friendly machining such as dry cutting, minimum quantity lubrication (MQL), cold air cutting and etc. have been proposed. In those reports, however, the effective application techniques of eco-friendly machining such as kinds and quantity of lubricant, cutting tool, cutting conditions have been determined experimentally.

The purpose of this study is to show the suitable application methods of eco-friendly machining. So, in this paper, transitional cutting temperature and cutting force that have the influence on tool wear were examined from points of intermittent cutting distance, cutting speed, feed rate and supply of cold air.

The results obtained are as follows. Cutting temperature rose rapidly during 30 times cutting distance to feed rate in start of cutting. The peak of cutting temperature fell with the decrease of feed rate. In this experiment, the cutting temperature fell about 10-40 degrees $C$ by supply of cold air.

Key Words : Cutting Temperature, Intermittent Cutting, Cold Air Cutting, Tool Life

\section{1. 楮寄}

従来, 切削加工では冷却，潤滑，切りくず排出を目的と し大量の切削油剂が用いられてきた. しかし, 切削油绪の 使用は作業環境の悪化, 油刜付着に伴う洗浄工程及び廃油 処理の必要性などの問題点が指摘されている.こうした背 景から環境負荷低減を目指した加工法の研究が稹極的に 行われている(1)(2). 具体的にはドライ切削, MQL 切削, 泠風切削 (3)などが提案されているが,これら加工法の油刜 を含めた適用方法, 工具形状・材料，さらに加工条件など については実験的に検討しているのが現状である.

そこで本研究では，㻴境対応加工法の選定指針を得るこ とを目的として，本稿では工具寿命に大きな影響を持つ切 削温度, 切削力について検討した。

\section{2. 実験装置及び方法}

環境対応加工法はフライス, エンドミル切削などのよう な断続切削過程で検討されている場合が多い.そこで断続 切削過程における過渡的な切削温度に着目し，切削速度， 送りなどの加工条件, 断続切削距離, さらにはそれらに対 する冷風による影響について調べた.ここでは切取り厚さ がー定である旋盤を用いた断続切削により検討を行った.

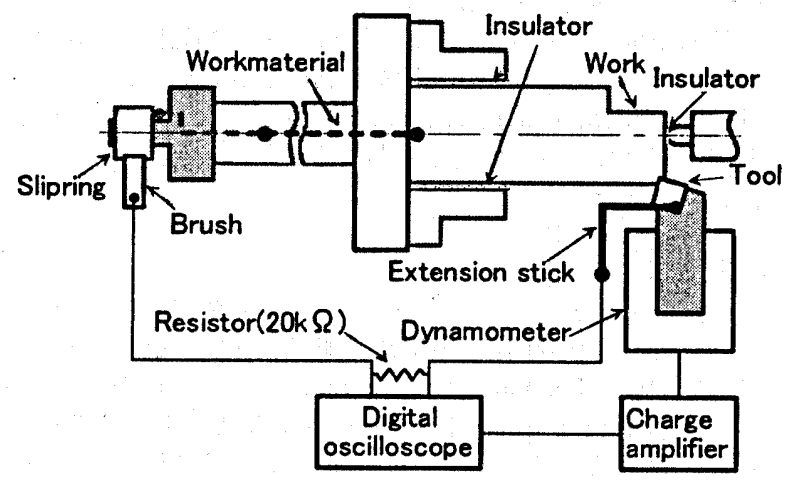

Fig.1 Schematic illustration of experimental equipment
実験装置の概略図を図 1 に示す，超硬（P20）工具によ る炭素鋼（S45C）の切削を対象とし，断続切削は被削材 の丸棒に满をつけて行った. 切削温度は工具 - 被削材熱電 対法を用いて測定した. 回転する被削材からの熱起電力の 取出しにはスリップリングを用いた. 工具 - 被削材熱電対 法では非切削期間中は測定することができず, 大きなノイ ズが入るため $20 \mathrm{k} \Omega$ の抵抗を並列に入れた. 切削力は圧電 式 3 分力動力計を用いて測定した. 冷風は泠却装固で熱交

Table 1 Cutting conditions

\begin{tabular}{c|c}
\hline Workpiece & Steel (S45C) \\
\hline Tool & $\mathrm{P} 20(-5,-5,6,6,15,15,0.4)$ \\
\hline Cutting speed & $100,200,300 \mathrm{~m} / \mathrm{min}$ \\
\hline Cutting distance & $6,75.6 \mathrm{~mm}$, continuous cutting \\
\hline Feed rate & $0.025,0.05,0.2 \mathrm{~mm} / \mathrm{rev}$ \\
\hline Depth of cut & $1.0 \mathrm{~mm}$ \\
\hline
\end{tabular}

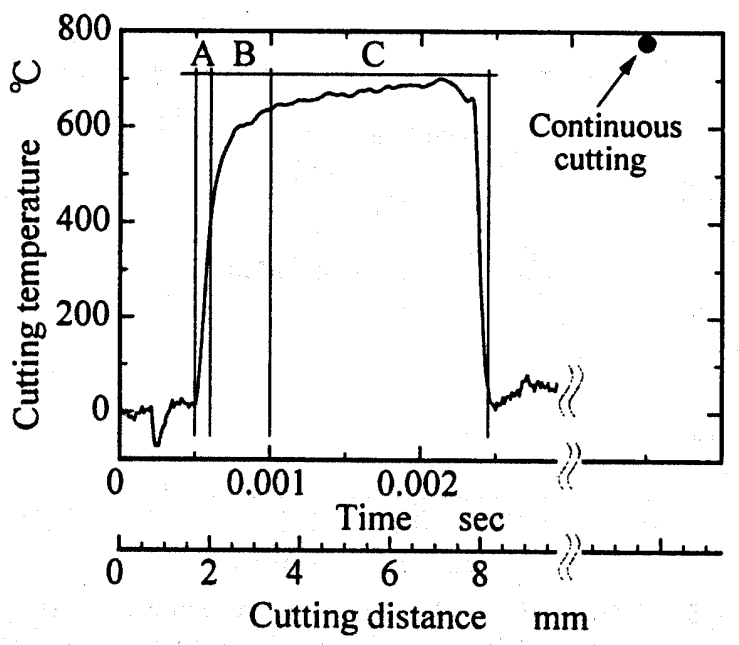

Fig.2 Transition of cutting temperature, cutting conditions; intermittent cutting distance $6 \mathrm{~mm}$, cutting speed $200 \mathrm{~m} / \mathrm{min}$, feed rate $0.05 \mathrm{~mm} / \mathrm{rev}$, depth of cut $1 \mathrm{~mm}$ 
換した約 $-35^{\circ} \mathrm{C}$ の圧縮空気を用いた. 冷風噴きつけノズル 位置については, ドライ切削時と比較して最も切削温度の 低下が見られた工具横切れ刃角に平行でななめ上方 $45^{\circ}$ 方向, 加工点から $10 \mathrm{~mm}$ の位置より供給した. デジタルオ シロスコープの測定サンプリング周期は $0.01 \mathrm{msec}$ で行っ た．本実験の切削条件を表 1 に示す.

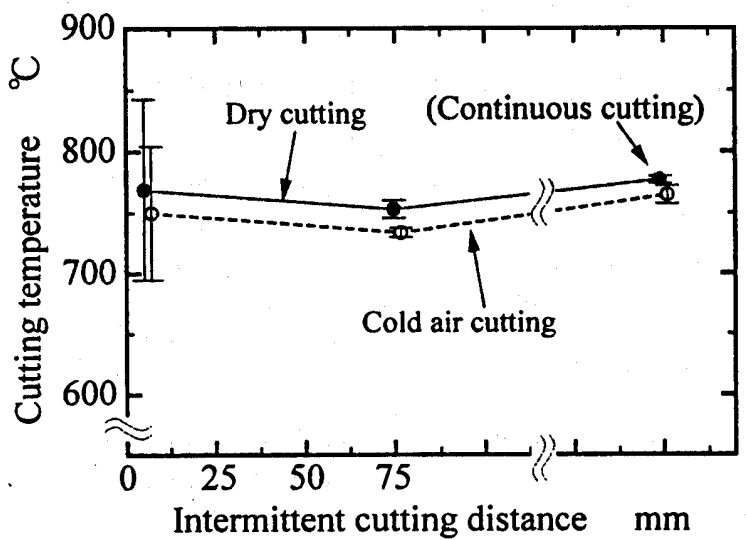

Fig.3 Effect of cutting distance on maximum cutting temperature, cutting conditions; cutting speed $200 \mathrm{~m} / \mathrm{min}$, feed rate $0.05 \mathrm{~mm} / \mathrm{rev}$., depth of cut $1 \mathrm{~mm}$

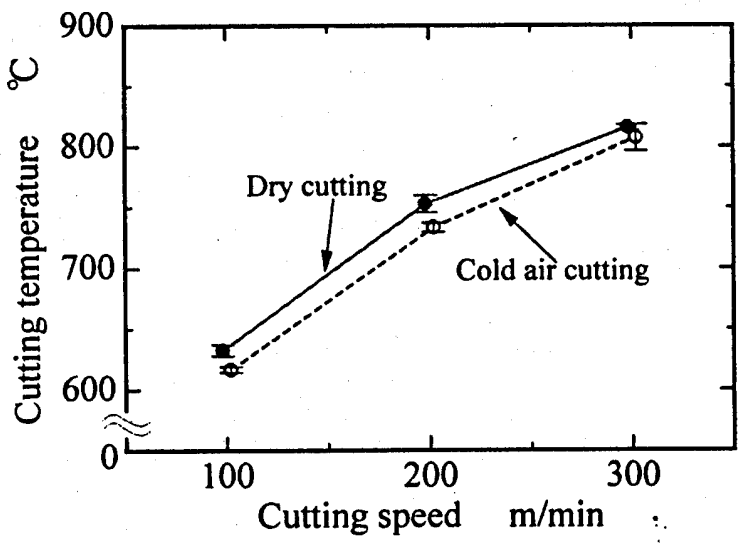

Fig.4 Effect of cutting speed on maximum cutting temperature, cutting conditions; intermittent cutting distance $75.6 \mathrm{~mm}$, feed rate $0.05 \mathrm{~mm} / \mathrm{rev}$, depth of cut $1 \mathbf{m m}$

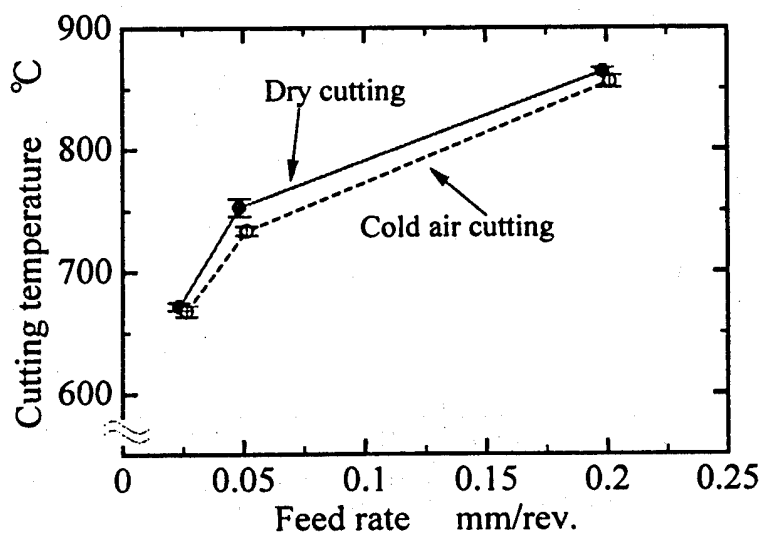

Fig.5 Effect of feed rate on maximum cutting temperature, cutting conditions; intermittent cutting distance $75.6 \mathrm{~mm}$, cutting speed $200 \mathrm{~m} / \mathrm{min}$, depth of cut $1 \mathrm{~mm}$

\section{3. 実験結果及び考察}

\section{1 過渡的な切削温度变化}

図 2 に切削開始からの切削時間に伴う切削温度の測定 例を示す. 図中に示すように切削開始直後の期間 A（切削 時間で $0.1 \mathrm{msec}$ 間，切削距離で $0.3 \mathrm{~mm}$ ）では切削開始とと もに切削温度は直線的な上昇を示している. 次に期間 B では, 切削温度の上昇はやや䋸やかになり, さらに期間 C では徐々に切削温度は上界し, 切削距離が長ければ定常状 態に至る. 切削温度の直線的な立ち上がりを示す期間 A では, 送りの 6 倍の切削距離で切削温度は定常状態の約 $50 \%$ ，期間 A と B を合わせる（切削距離 $1.7 \mathrm{~mm}$ ） と送り の 30 倍程度の切削距離で定常状態の約 $80 \%$ に達している. このことから切削過程の初期に切削温度が急激に上昇し ていることがわかった. 特に期間 A での切削温度上界は 切りくず生成のための塑性変形域の急激な桩大と対応す るものと考えられる.

\section{2 断続切削距離の影品}

断続切削距離が短ければ, 切削温度は定常状態には至ら

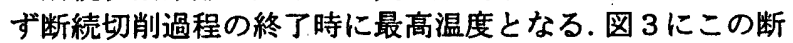
続切削距離と最高切削温度の関係を示す. 断続切削距離 $6 \mathrm{~mm}$ での測定結果はばらつきがあるが, 図 2 と合わせて 考えると，切削温度が過渡的に上昇している期間に切削が 終了することから，断続切削距離を短くすると最高切削温 度が低くなっているのがわかる. 冷風による切削温度の低 下については, 断続切削距離による影響は見られなかった。 3. 3 切削速度の影響

図 4 に切削速度と最高切削温度の関係を示す. 従来知ら れているように切削速度の増加とともに最高切削温度は 上昇していることがわかる. ドライ切削時と比較すると冷 風切削時ではすべての切削速度領域で約 $20^{\circ} \mathrm{C}$ 切削温度 の低下が見られた. また, 切削開始直後（図 2 の期間 $\mathrm{A}$ に相当)での切削温度上昇速度は切削速度の増加に伴い大 きくなっていた. 以上の傾向は断続切削距離を変化させて も同様であった. なお, 切削速度 $100 \mathrm{~m} / \mathrm{min}$ 末満では構成 刃先が生じることから検討していない.

\section{4 送りの影響}

図 5 に送りと最高切削温度の関係を示す. 送りの減少と ともに切削温度は低くなり，特に低送り領域で著しく温度 が低くなっていることがわかる. 冷風により約 $10 〜 20^{\circ} \mathrm{C}$ の切削温度の低下が見られた. また, 切削開始直後の切削 温度上昇速度には影著な差は見られなかった。

なお, 切削力については主分力, 送り分力, 背分力とも にドライ切削と冷風切削で顕著な差は見られなかった。

\section{4. 結震}

断続切削過程において断続切削距離, 切削速度, 送りお よび椧風の供給が過渡的な切削温度, 切削力に及ぼす影響 について検討を行った.

切削温度については送りに対して 30 倍程度の切削距離 という切削過程の初期に急激に上昇すること. また, 送り が小さくなれば切削温度が低下することなどがわかった. 本㥶験範囲では冷風による最高切削温度の低下は約 10〜 $40^{\circ}$ Cであった.

\section{参考文献}

（1）松原十三生 : 最近のエコマシニング技術, 精密工学 会秋季大会学術講演会講演論文集, (2000)183.

(2) J.W.Sutherland : An Experimental Investigation of Air Quality in Wet and Dry Turning, CIRP, 49, 1(2000)61.

（3）横川宗彦：“環境”“省エネ”に対応する工作機械と 加工技術, 機械と工具, 7(2000)14. 